\title{
Plasmodium falciparum and placental cytokine profiles among pregnant women in relation to their HIV-I status: possible implications for mother-to-child transmission (MTCT) of HIV-I in Cameroon
}

\author{
Anfumbom Kfutwah*1, Jean Yves Mary², Brigitte Lemen ${ }^{3}$, Robert Leke ${ }^{4}$, \\ Dominique Rousset ${ }^{1}$, Françoise Barré-Sinoussi ${ }^{5}$, Eric Nerrienet ${ }^{1}$, \\ Elisabeth Menu ${ }^{5}$ and Ahidjo Ayouba ${ }^{1}$
}

\begin{abstract}
Address: ${ }^{1}$ Virology laboratory, Centre Pasteur du Cameroun, BP 1274 Yaoundé, Cameroon, ${ }^{2}$ INSERM U717, Université Paris 7, DBIM, Hôpital St Louis, 75010 Paris, France, ${ }^{3}$ Centre d'Animation Sociale et Sanitaire (CASS) Nkoldongo, Yaoundé, Cameroon, ${ }^{4}$ The maternity of the Central Hospital, Yaoundé, Cameroon and ${ }^{5}$ Unité de Régulation des Infections Rétrovirales, Institut Pasteur, 75015 Paris, France

* Corresponding author
\end{abstract}

from Fourth Dominique Dormont International Conference. Host-Pathogen Interactions in Chronic Infections Paris, France. 13-15 December 2007

Published: 9 April 2008

Retrovirology 2008, 5(Suppl I):OI4 doi:I0.II86/I742-4690-5-SI-OI4

This abstract is available from: http://www.retrovirology.com/content/5/SI/OI4

(c) 2008 Kfutwah et al.; licensee BioMed Central Ltd.

\section{Background}

Placental cytokines play vital roles in establishing and maintaining pregnancy as well as protecting the fetus from in utero infections. Previous studies have strongly suggested the implication of co-infections such as $P$. falciparum in the in utero MTCT of HIV-1 [1][2][3]. This study was designed to assess the impact of $P$. falciparum on the influence of HIV-1 infection on placental cytokine profile and the association of these profiles with clinical factors known to be related to HIV-1 MTCT.

\section{Materials and methods}

$P$. falciparum was tested in the peripheral and/or placental blood from 50 and 80 HIV-1 negative and positive women respectively. Cytokines (proteins) were quantified in the supernatants of 24 hours culture of placental explants by ELISA while cytokine mRNAs were quantified in placental tissue by real time PCR. Antibodies to the DBL3 $\gamma$ domain of PfEMP1 that binds $P$. falciparum infected red blood cells to placental CSA were titrated by ELISA in sera. The comparisons of the levels of cytokine proteins and mRNAs, as well as of anti-DBL3 $\gamma$ antibodies between HIV-1 negative and positive women who were either $P$. falciparum negative, or positive in the periphery or placenta, were tested through non-parametric tests, as well as the associations between cytokine profiles and clinical factors.

\section{Results}

Placental and peripheral P. falciparum infection was comparable in both HIV-1 negative and positive women (from 18 to $24 \%$ ). Conversely $P$. falciparum parasitemia was significantly higher in the HIV-1 positive group. Large individual variations were observed in placental cytokine proteins and mRNA expression in each group. No significant differences were observed between placental cytokine median levels (protein and mRNA) in HIV-1 negative and positive women. However, among $P$. falciparum negative women, we observed significant differences in several cytokine median levels (TNF- $\alpha$, IL-10, IL-16, IL-7, LIF, and RANTES) between HIV-1 negative and positive women. Median levels of antibodies to DBL3 $\gamma$ were significantly higher in the HIV-1 negative group $(\mathrm{p}=0.03)$ and was dependent of peripheral and placental P.falciparum infection. TNF- $\alpha$ among the HIV-1 positive women was the only cytokine associated with clinical parameters linked to HIV-1 MTCT (premature rupture of membranes, number of pregnancies and parity; $\mathrm{p} \leq 0.04$ ). 


\section{Conclusions}

Altogether these results highlight the reciprocal influence of both infections at the materno-fetal interface that might have possible implications for in utero HIV-1 MTCT in areas where HIV-1 and $P$. falciparum co-circulate.

\section{Acknowledgement}

This work is presented on behalf of the ANRS I 267 study team and the HIV-I PMTCT-PlaNet.

\section{References}

I. Ayisi JG, van Eijk AM, Newman RD, ter Kuile FO, Shi YP, Yang C, Kolczak MS, Otieno JA, Misore AO, Kager PA, et al.: Maternal malaria and perinatal HIV transmission, western Kenya. Emerg Infect Dis 2004, I 0(4):643-652.

2. Brahmbhatt H, Kigozi G, Wabwire-Mangen F, Serwadda D, Sewankambo N, Lutalo T, Wawer MJ, Abramowsky C, Sullivan D, Gray R: The effects of placental malaria on mother-to-child HIV transmission in Rakai, Uganda. AIDS 2003, I 7(I 7):2539-254I.

3. Ayouba A, Nerrienet E, Menu E, Monny Lobé M, Thonnon J, Leke RJI, Barré-Sinoussi F, Martin PMV, Cunin P, for the Yaoundé MTCT group: Mother-to-Child transmission of HIV-I in relation to the season in Yaoundé, Cameroon. Am J Trop Med Hyg. 2003, 69:447-449.

Publish with Bio Med Central and every scientist can read your work free of charge

"BioMed Central will be the most significant development for disseminating the results of biomedical research in our lifetime."

Sir Paul Nurse, Cancer Research UK

Your research papers will be:

- available free of charge to the entire biomedical community

- peer reviewed and published immediately upon acceptance

- cited in PubMed and archived on PubMed Central

- yours - you keep the copyright

Submit your manuscript here:

http://www.biomedcentral.com/info/publishing_adv.asp 